\title{
Virtuelle lærings- og kommunikations- miljøer i rehabiliteringen af mennesker med afasi
}

\section{Ulla Konnerup}

\author{
Ph.D. stipendiat, master i ikt og \\ læring \\ Aalborg Universitet
}

Afasi er en betegnelse for forstyrrelser af sprogfunktionen efter en hjerneskade. Skaden kan være opstået efter en blodprop, hjerneblødning eller traumer, men kan også skyldes andre skader, hvor hjernens blodkar er læderet. Afasi medfører kommunikationsforstyrrelser i varierende grad, alt efter hvor i hjernen, skaden er. Kun i sjældne tilfælde vil der være tale om et fuldstændigt tab af sprogfunktionen. Afasi påvirker evnen til at producere og forstå tale/sprog, samt evnen til at læse, skrive, stave og regne. Der kan være problemer med at bruge ja/nej korrekt, kende og anvende genstande. Afasi kan være ledsaget af andre symptomer f. eks. lammelse, svigtende hukommelse, opmærksomhedsproblemer og besvær med at koncentrere sig. I Danmark rammer afasi hvert år 3.500 mennesker. Taleinstituttet, Region Nordjylland får hvert år ca. 500 nye afasiramte henvist 


\section{Abstract}

Virtuelle læringsmiljøer ${ }^{1}$ giver nye muligheder i rehabiliteringen af afasiramte - både i forhold til genoptræning af sprog, sociale relationer og $\mathrm{i}$ forhold til det at genskabe sig selv og sin identitet efter en hjerneskade.

Artiklen bygger på forfatterens erfaringer som talepædagog på Taleinstituttet i Nordjylland med undervisning af afasiramte, på Aalborg Universitets følgeforskning af projektet Ansigt til Ansigt (Petersen et. al 2004), samt på Dorte Schmidt's og forfatterens og case-studie af den virtuelle læringsog kommunikationsplatform Basecube (Konnerup \& Schmidt 2006). Artiklen sætter fokus på sproglig rehabilitering understøttet af web 2.0værktøjer, og den beskriver, hvorledes inddragelse af virtuelle sociale fællesskaber og emotion i undervisningen af afasiramte giver mulighed for at sætte sig igennem i handling, socialisering og kommunikation.

Til forståelse af hvor indgribende en erhvervet sprogforstyrrelse kan være for et menneskes mulighed for at lære, erkende, kommunikere og indgå i sociale sammenhænge inddrages teori om sprog, identitet, kognition og seneste hjerneforskning. Artiklen perspektiveres med, hvorledes inddragelse af undervisning i et immersivt virtuelt læringsmiljø kan bibringe nye muligheder for rehabilitering af hjerneskadede. Specielt interessant er her den avatar-medierede og den kropslige 'immersion', da målgruppen enten har fysiske eller kognitive begrænsninger og handicaps.

\section{Indledning}

Taleinstituttet i Region Nordjylland (TI) har siden 2001 haft et webbaseret genoptræningstilbud til mennesker med afasi. Først som et fjernundervisningsprojekt, Ansigt til Ansigt (ATA) under det Digitale Nordjylland (DDN) i årene 2001-2004, hvor undervisningen foregik via videokonferencer og opgaver sendt via mail. Formålet med DDN projektet var at etablere et fjernundervisningstilbud til personer med afasi, der kunne effektivisere genoptræningen. Metoden skulle give mulighed for at tilpasse undervisningen og træningen til den enkeltes "energimønster" med høj grad af fleksibilitet af tid og indhold og således tilgodese afasiramtes behov for en tilgængelig brugerflade og muligheden for at kombinere forskellige perceptionsformer. Med undervisning i hjemmene blev det muligt i højere grad at involvere de pårørende. Hensigten var at give de afasiramte mulighed for at lære/eller genlære ikt, øge generelle kommunikationskompetencer, styrke deres deltagelse i samfundsdebatter og øge deres selvhjulpethed i forhold til ehandel/e-banking (Petersen et al. 2004).

Prof. Lone Dirckinck-Holmfeld, E-learning Lab (AAU), stod for følgeforskning af ATA. Forskningen var dialogbaseret på baggrund af videooptagelser, interviews og dagbøger fra repræsentative deltagere. Hovedkonklusionen blev, at projektet var en succes i forhold til undervisning af målgruppen, og at træning praktiseret som e-læring $2 \mathrm{i}$ hjemmet på fleksible tidspunkter fremmer motivation og engagement - både for den afasiramte selv og i forhold til invol-

\footnotetext{
1 Forstået som læringsomgivelser/miljøer, hvor infrastruktur og læreprocesser er medieret af informations- og/eller kommunikationsteknologi (ikt).

2 Forstået som læring og læringsobjekter, som styrkes gennem anvendelse af informationsog/eller kommunikationsteknologi (ikt).
} 
veringen hos pårørende. I evalueringen var nogle af nøgleordene om undervisningsformen: fleksibilitet, udadvendthed, motivation, ansvar for egen læring og overskud. Den psykologiske faktor nævnes endvidere som en sideeffekt: "Mediet - computeren - medvirker til at styrke den del af den afasiramtes identitet, de har med sig fra før de blev ramt! Det er nemt og "værdigt" at delagtiggøre venner og familie" (Petersen et al. 2004).

E-læring på Taleinstituttet har siden udviklet sig til - ud over at være et fjernundervisningsprojekt med fokus på de teknologiske muligheder - at indgå differentieret og fleksibelt i genoptræningen, tilpasset den enkelte afasiramtes behov med inddragelse af nyere ikt-værktøjer, herunder web 2.0 teknologier (Konnerup \& Schmidt 2006).

E-læring i det talepædagogiske arbejde har været og er stadig til diskussion blandt talepædagoger. Et dominerende undervisningssyn inden for fagområdet har sat menneske-menneske interaktionen i højsædet, hvilket har været svært foreneligt med anvendelsen af computere, da man så en risiko for, at disse ville medføre et ekstra forstyrrende element $i$ kommunikationen mellem mennesker, der havde kommunikationsvanskeligheder (ibid.). Indenfor det talepædagogiske område har der været mere fokus på de teknologiske muligheder for at forbedre talen og sprogproduktionen end på det kommunikative, deltagende og meningsdannende aspekt (Petheram 2004). Manglende evidens for computerens effekt affødte endvidere en vis skepsis (Gade 1992), og det var først i 2001, at man via midlerne fra DDN i Nordjylland fik mulighed for at sætte målrettet fokus på mulighederne for at inddrage kommunikationsteknologi i Danmark (Konnerup \& Schmidt 2006).

Fra at se informationsteknologiske muligheder som en måde at effektivisere afasiundervisningen på, eksempelvis ved at spare transport ved fjernundervisning, og ved at erstatte menneskelig interaktion med computerprogrammer, bidrog Taleinstituttets projekter og den tilknyttede forskning til, at der i den afasipædagogiske praksis i Danmark blev sat fokus på at se på de nye kommunikations- og læringsmæssige muligheder, ikt tilbyder. I takt med den teknologiske udvikling og den kendsgerning, at en markant større del af målgruppen ${ }^{3}$ allerede har ikt-kompetencer og har anvendt internet og mobilteknologi inden deres skade, stilles endvidere nye krav til de tilbud, der gives til mennesker med erhvervede hjerneskader.

\section{Sprog og hjerneforskning}

For at forstå begrænsninger og muligheder for læring efter en hjerneskade, beskrives sprogets betydning for erkendelse og tænkning, samt hvordan vi kan inddrage den seneste hjerneforskning til at tænke i nye genoptræningsmuligheder. Herefter uddybes Taleinstituttets erfaringer med virtuelle genoptræningsmuligheder.

\footnotetext{
${ }^{3}$ I 2009 havde 86 pct. af befolkningen adgang til Internettet i hjemmet mod 59 pct. i 2001. Der har været en jævn stigning i adgangen til Internettet. Kilde Danmarks Statistik: http://www.dst.dk/HomeDK/Statistik/ags/IT.aspx
} 


\section{Sprogets betydning for erkendelse og tankning}

Sproget har mange udtryksformer og repræsenterer sig som talt sprog, kropssprog, billedsprog, samt læsning og skrivning. Sproget skal ikke ses som et mål i sig selv, men funktionalistisk som et middel til kontakt, kommunikation og læring. For at indkredse begrebet sprog, er det nødvendigt at medtage både den lingvistiske og den psykologiske dimension. Herved bliver det muligt "at beskrive sprogbrugen som en handling, der har bestemte formål ... og at beskrive sproget og dets struktur ud fra, hvad det bruges til af mennesker, der handler og opfatter i bestemte situationer" (Nicolaisen \& Vejleskov 1996:12). De sproglige processer er yderst komplekse og involverer flere områder af hjernen på én gang. Man kan groft skelne mellem ekspressiv og impressiv taleaktivitet. Ekspressiv tale bringes til udførelse ved hjælp af indre tale, der med grundlag i en plan omkodes i verbal form til et taleudtryk og bliver berettende tale. Den impressive tale, sprogforståelsen, er betinget af at kunne sammenkæde en lang række delelementer, nemlig: en akustisk perception, udskillelse af fonemer, forståelse af meningen bag det hørte, en evne til at bevare udtrykket i hukommelsen og endeligt kunne overskue talestrukturens elementer og forme dem til et logisk skema (ibid:268). Sproget kan karakteriseres som en i-talesættelse af en person og således som en del af hele vores identitet.

Ud over at være et kommunikationsmiddel spiller sproget en vigtig rolle for erkendelsen. Vygotsky var optaget af sammenhængen mellem sprog og tænkning og tillagde sproget en vigtig rolle i social interaktion. Sproget er grundlæggende for perception, hukommelse og tænkning og bliver herved et redskab for intellektuel aktivitet. Sproget har endvidere en regulerende funktion med betydning for planlægning og styring af adfærd (Vygotsky 1971). Tilegnelsen af sproget er tæt forbundet med erfaring og handling som leg, indøvelse og praksis. Sprog og tanke er uløseligt forbundet, og livet igennem styrer det vores erkendelse og oplevelse af verden. Forholdet mellem tanke og ord er en levende proces. "Tanken fødes med ordet. Et ord uden tanke er en død ting, og en tanke, som ikke legemliggøres i ord bliver skygge" (ibid.).

\section{Hjerneforskning}

Hjernen består af et komplekst netværk af nerveceller, der er forbundne af nervebaner. Den seneste hjerneforskning har vist, at nerveceller kan formere sig hele livet, at der ved beskadigede nerveceller kan dannes nye udløbere, der udvikler sig på grundlag af stamceller, og at nerveceller kan dele sig, hvis de stimuleres (Bjarkam 2004, Goldberg, 2005, Fredens 2004). Samtidig er det påvist, at nogle hjerneceller, såkaldte spejlneuroner, reagerer aktivt på andre menneskers handlinger på samme måde, som hvis man selv havde udført disse - altså at hjernen aktiveres gennem forestillinger om handlinger (Rizzolatti 2008). Hvis nervesystemet udfordres og stimuleres, og sanser og følelser påvirkes, sætter neuroplasticiteten mennesket i stand til at lære hele livet selv efter en hjerneskade. Hjernen udvikles ved at udfordres, og kontekst og feedback spiller en afgørende rolle for muligheden for at lære (Bjarkam 2004, Fredens 2004, Goldberg 2005, Konnerup og Schmidt 2006). 
Med udviklingen af nye bioteknologiske registreringsmuligheder ${ }^{4}$ er det i dag muligt både at se hjernestrukturer, studere hjernens aktivitet og få et indblik i elektriske og kemiske processer. Forståelsen for hjerneprocesser, skaders lokalisation og hvilke områder i hjernen, der spiller sammen, er således blevet udvidet. Den funktionelle billeddiagnostik af hjernen viser, at sproget ikke knytter sig til afgrænsede områder, men er "distribueret" i hele neocortex 5 . (Goldberg 2005). Sproget kan beskrives som en emergent størrelse, "der muliggøres, når hjernens neurale kredsløb har nået en vis grad af kompleksitet" (ibid:106). I Goldbergs forståelse formes sproget altså ikke kun af specifikke forhold i den neurale organisering, men i høj grad af sociokulturelle forhold (ibid.). På grundlag af kliniske erfaringer og bioteknologiske muligheder deles en dynamisk forståelse af hjernen i dag af flere hjerneforskere. Hjernens fleksibilitet bevares længere, end man før mente. Rehabilitering handler ikke kun om omstrukturering i de funktionelle systemer, men også om udfordringer og aktivitet. Den neuropsykologiske viden, man via test og hjernescanninger kan få om en hjerneskades anatomiske lokalisation og medførende forstyrrelser, skal omsættes til pædagogisk praksis. Et menneskes hjerneskade, følgevirkninger og udviklingsmuligheder skal forstås i et samspil mellem den biologiske skade og de psykologiske og sociale aspekter. Rehabiliteringen vil oftest finde sted i både et sundhedssystem og i et undervisningsmiljø, og således være præget af to videns- og menneskesyn: et naturvidenskabeligt behandlingssystem og et pædagogisk humanvidenskabeligt. Allerede under hospitalsindlæggelsen iværksættes talepædagogisk og fysio/ergoterapeutisk træning. Begrebet neuropædagogik fører de to videnskabssyn sammen og er udtryk for en samlet indsats i rehabiliteringen. Der er fokus på læring og den hjerneskadede som aktiv medspiller, hvor både de neuropsykologiske og de personlige og sociale aspekter medtænkes.

\section{Social interaktion og evnen til at opretholde sig selv som menneske}

Tages udgangspunkt i de grundlæggende betragtninger om sammenhængen mellem sprog og mental aktivitet må det antages, at det at få afasi også vil påvirke den ramtes selvforståelse og få konsekvenser for identitet og måske medføre psykiske problemer. Sprogvanskeligheder gør det svært at kommunikere med omgivelserne, hvorved muligheden for at afprøve sine tanker og meninger svækkes. Herigennem svækkes også evnen til at fastholde egne meninger og tanker - tankeprocesserne besværliggøres. En person med sprogvanskeligheder vil kunne opleve ændringer i omverdenens måde at forholde sig og reagere på - man bliver set som en anden person med en anden identitet (Vestberg 2002). Sociale relationer kan være svære at opretholde, fordi kommunikationen bliver vanskeliggjort, ligesom det bliver vanskeligt at påvirke omgivelserne. Ændres vores sprog, påvirker dette i stor udstrækning andres opfattelse af os, med den konsekvens, at identitetsopfattelsen ændres (Svenstrup 2004). En person med afasi kan opleve ikke at være sig selv mere.

\footnotetext{
${ }^{4}$ CT-scanning (computeraksialtomografi) eller MRI (magnetisk ressonansscanning) er former for strukturel billeddiagnostik, der gør det muligt at se hjernens strukturer. fMRI (funktionel magnetisk resonnansscanning), PET (positronemissionstomografi), SPECT (enkeltfoton-emissionstomografi) og MEG (magnetencefalografi) er former for funktionel billeddiagnostik, der viser hjernens aktivitet (Goldberg 2005:244).

${ }^{5}$ Storhjernen.
} 
Tab af den sproglige kompetence får afgørende konsekvenser af såvel social karakter som i forhold til identitet, tænkning, erkendelse og læring. Hvis ikke det er muligt at finde alternativer og kompensationsstrategier for deltagelse og meningsforhandling, er det sandsynligt, at det intellektuelle niveau gradvist vil falde. "Det siges ofte, at en persons sprog er på samme niveau som vedkommendes intelligens. Det er formentlig i vidt omfang korrekt. Men det modsatte gælder også: Din intelligens er på niveau med dit sprog" (Goldberg 2005:109). Hvis dette er korrekt, fortæller det noget om, hvor indgribende en sprogforstyrrelse er for et menneskets mulighed for at udvikle sig og vedblive med at være sig selv.

\section{Basecube}

På baggrund af erfaringerne fra ATA udviklede virksomheden Groubee i samarbejde med talepædagoger og afasiramte et webbaseret virtuelt læringsog kommunikationsfællesskab, Basecube (Pettersson 2004). Målet var netop med et socialkonstruktivistik syn på genoptræning at udnytte de nyeste teknologier, web 2.0, til at give afasiramte mulighed for lære gennem refleksion og interaktion, kombinere flere perceptionsformer og asynkron/synkron kommunikation, samt give mulighed for ansvar for egen læring. For at imødekomme målgruppens specielle krav til et lettilgængeligt og brugervenligt design og eventuelle kognitive problematikker, som eksempelvis vanskeligheder med hukommelse, struktur og navigation, er kommunikations- og e-læringsfunktioner på Basecube samlet på én oversigtside (figur 1). I designet er der endvidere lagt vægt på at udnytte de potentialer, ikt har i sig til at strukturere og anvende billeder til at få ideer, erindre, interagere, manipulere og eksperimentere, samt påvirke følelser og stimulere til handling.

\section{Undervisningen i praksis}

Afasiramte skal visiteres til adgang til Basecube og være tilknyttet en talepædagog. Dette begrænser deltagerantallet, men sikrer samtidig en intimitet og tryghed, der for nogle er nødvendig for aktiv deltagelse. De tilbud, der gives, er differentierede og spænder fra muligheden for at være perifer deltager, der blot har glæde af at "se med", til at få flere opgaver ugentligt, der løses og debatteres skriftligt asynkront med synkron opfølgning på Skype. Opgaverne udarbejdes i en skabelon af talepædagogerne og er individuelt tilpassede. Det er muligt at oploade den samme opgave til én eller flere. De udarbejdede opgaver lagres i et fælles opgavearkiv tilgængeligt for alle tilknyttede talepædagoger, hvorfor det er muligt at dele, genbruge og tilpasse opgaverne på ny.

Der findes 3 former for debat i Basecube (figur 2). Den kommunikation, der foregår om en opgave er tovejs mellem afasiramt og talepædagog, og tjener både til debat, til afklarende spørgsmål og til at styrke og forberede impressivt ramte til synkron samtale.

Den dialog og meningsforhandling, der foregår mellem afasiramte sker via debattråde i et debatforum eller som kommentarer til artiklerne (figur 3). Det er muligt for alle at oprette en debattråd målrettet specifikke grupper i systemet. 


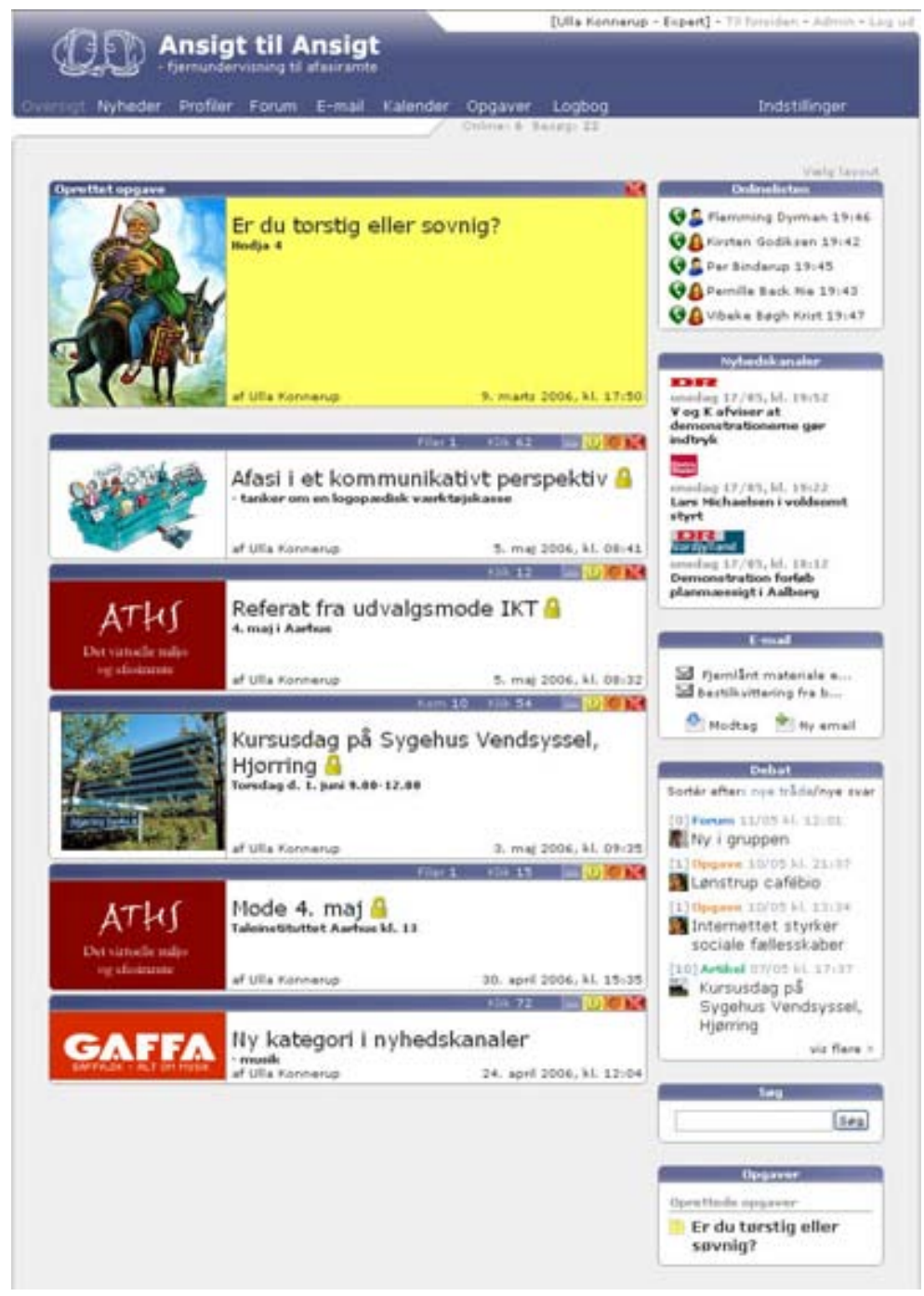

Figur 1. Eksempel på en oversigtsside i Basecube

Sortér efter: nye trăde/nye svar

[8] Artikel 30/03 kl. 01:36

F. De kognitive funktioner

[4] Forum 29/03 kl. 12:44

B.

[2] Opgave 24/03 kl, 09:20

Skift til sommertid

[2] Artikel 24/03 kl. 07:34

Ad Fortællinger og erfaringer

[4] Dpgave $23 / 03 \mathrm{kl}, 08: 56$

[y I fredags blev jeg svensker

[8] Opgave $22 / 03 \mathrm{kl}, 14: 56$

Skift til sommertid

vis flere *

Figur 2. Tre former for debat, signaleret med hver sin farve 


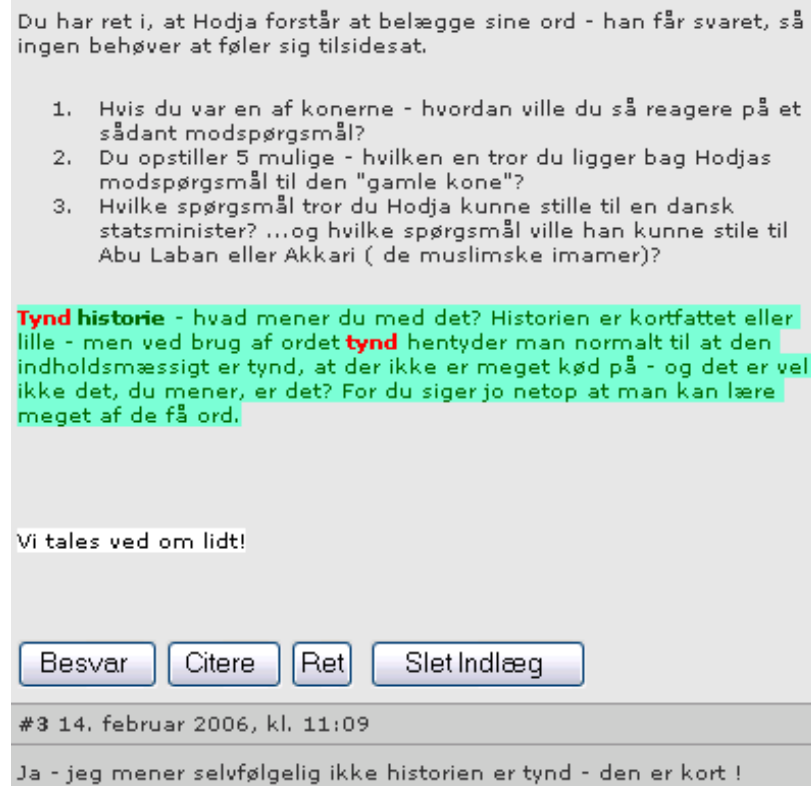

1. Huis du var en af konerne - huordan ville du să reagere pă et sådant modspørgsmăl?

2. Du opstiller 5 mulige - huilken en tror du ligger bag Hodjas modspørgsmăl til den "gamle kone"?

. Huilke spørgsmăl tror du Hodja kunne stille til en dansk statsminister?... og huilke spørgsmăl ville han kunne stile til Abu Laban eller Akkari (de muslimske imamer)?

Tynd historie - huad mener du med det? Historien er kortfattet eller lille - men ved brug af ordet tynd hentyder man normalt til at den indholdsmassigt er tynd, at der ikke er meget $k ø d p a-o g$ det er vel ikke det, du mener, er det? For du siger jo netop at man kan lære meget af de fă ord.

Vi tales ved om lidt!

Besvar Citere Ret Slet Indlaeg

\#3 14. februar 2006, kl. 11:09

Ja - jeg mener selufølgelig ikke historien er tynd - den er kort !

Figur 3. Skriftlig dialog som støtte for den synkrone mundtlige dialog.

Jeg vil lige ogsă være med $\mathrm{i}$ din rejser. Jeg var i USA to år før jeg var syg. Det var sa meningen jeg skule det $\mathrm{i}$ ăr ogsă. Men jeg tør ikke rejse alene, forde jeg har faget at mine atjeg kan fog en blodprop $i$ mine ben. Jeg er ogsa bange for at jeg ikke kan klare, at finde rundt $i$ luftenhaven og alle de lyde der er. Men măske kan jeg klare det til næeste ăr, det hăber jeg meget.

Hilsen

\section{Besvar Citere Slet Indlæeg}

\#24 16. november $2005, \mathrm{kl} .17: 55$

Hej

Tak for besuarelsen. Huor lange er det siden du blev syg? Jeg kan godt forsta at du ikke kan rejse selu - jeg har rejst med min mand og børn - ellers var jeg ikke kommet nogle vejne! Det med at "klare lufthavnens larm" - for "os" kan lade sig gøre at tăle bedre sğ det kan da godt være at du kan næste ăr! - har du prøvet at køre en læengere tur f.eks, til Tyskland? - hwordan gik det? Hilsen

Figur 4. Debat melælem afaseramte om begrænsninger i rejseaktivitet. 


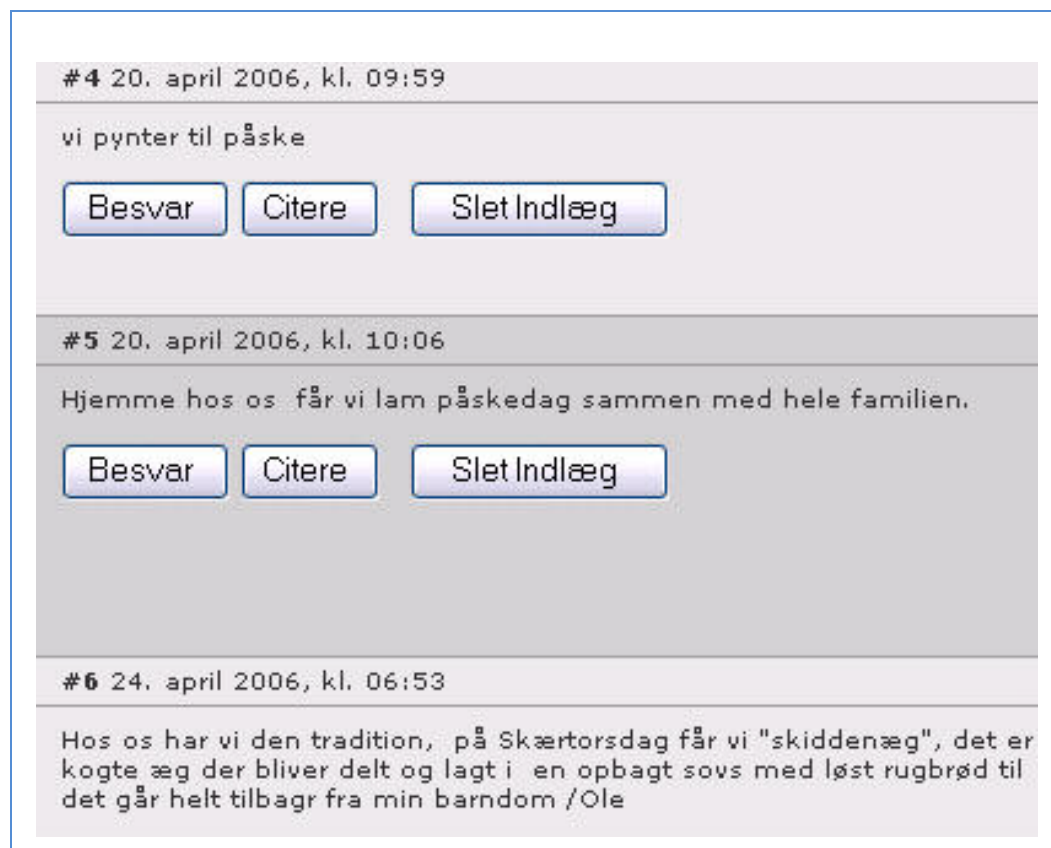

Figur 5. Indlæg om påsketraditioner

Indlæggene har karakter af både seriøse problemstillinger relateret til konsekvenserne af en hjerneskade og mere muntre videoklip, sange og vittigheder. Trådene har billeder ud fra indlæggene for at tydeliggøre afsenderen. Debatten kan også være på baggrund af en artikel i Basecube, enten om nye muligheder eller oplæg med opfordringer til at udveksle erfaringer.

Ideen bag de forskellige debatmuligheder er både at fremme kontakten og dialogen de afasiramte imellem og at udvide kommunikationen mellem talepædagog og afasiramte, således at diskussioner og spørgsmål af almen interesse, som eksempelvis respons på deltagelse i kurser og spørgsmål til nye værktøjer, ligger åbent og tilgængeligt for alle.

Alle deltagere har en profilside (figur 6), hvor de har mulighed for at skrive oplysninger om sig selv, skrive fritekst, foretrukne links, kompetencer og blogs, og hvor der er mulighed for at oploade multimedier.

De læringsmuligheder, der ligger i Basecube er således dels af individuel karakter, hvor der løses specifikt målrettede opgaver, dels af social karakter med læring i form af interaktion med mediet, diskussion og selvpræsentation.

Der er mulighed for at oprette logbøger (figur 7), og definere hvem der skal have henholdsvis læse- og/eller skriverettigheder. Der er også et privat skrivebord med mulighed for at oploade filer. 

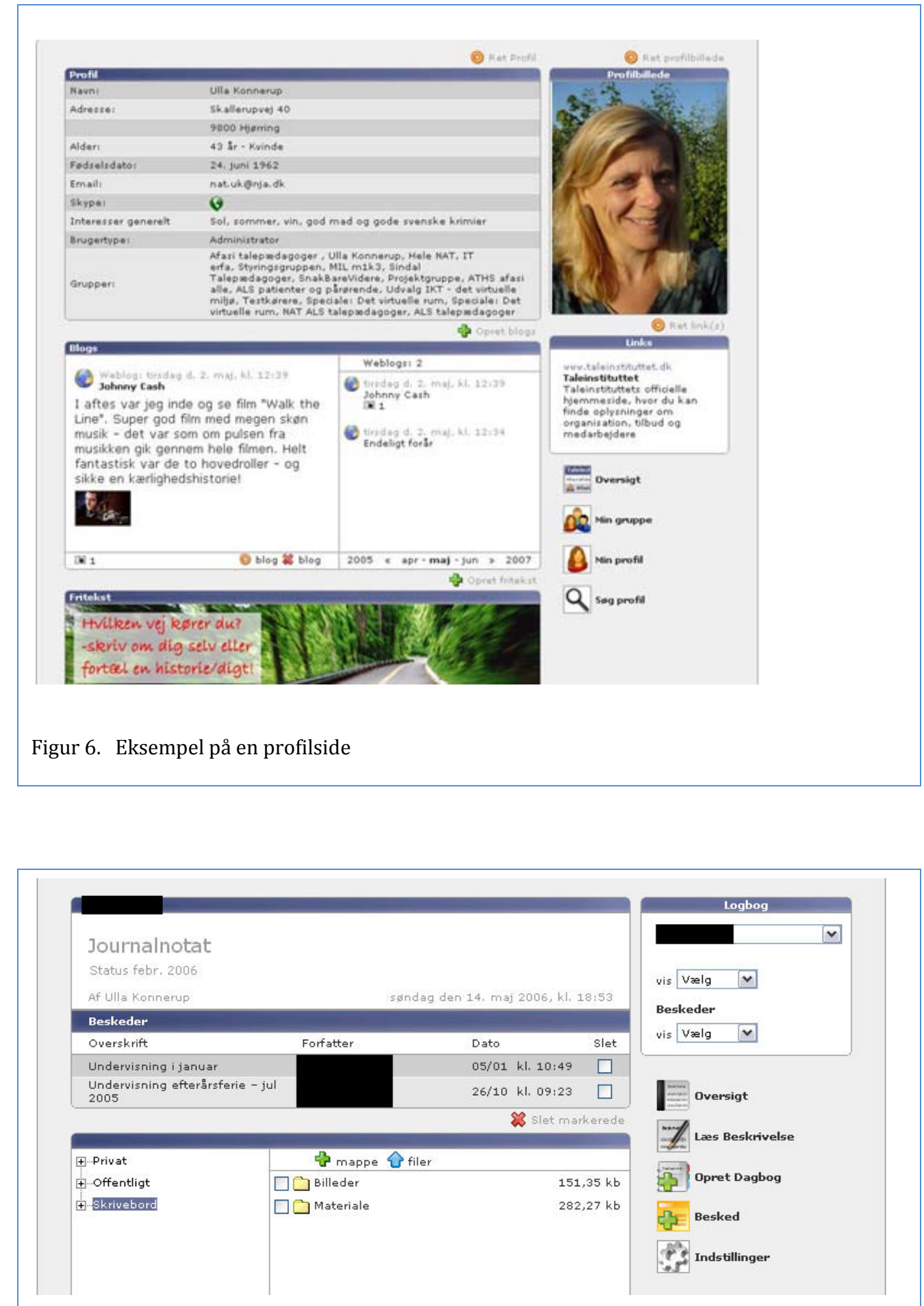

Figur 7. Eksempel på en logbog. 


\section{Kognitiv fitness i et virtuelt fællesskab}

I genoptræning efter en hjerneskade skal talepædagogen tage højde for det kognitive funktionstab, der er sket, og søge at styrke alternative eller kompenserende strategier. Den undervisning, der praktiseres via Basecube, afspejler et læringssyn, hvor den kognitive rehabilitering ses i en sociokulturel forståelse, hvor det kognitive har mulighed for at udvikle sig $i$ og motiveret $a f$ sociale fællesskaber. Samtidigt er metodikken et alternativ til undervisning, der isoleret arbejder med reetablering af sprogproduktionen.

Det er en del af talepædagogens praksis at afdække omfang og karakter af hjerneskaden. I dag supplerer hjernescanninger talepædagogens pædagogiske diagnose med en medicinsk diagnose. På baggrund af en udredning af tabte og bevarede kognitive og sproglige funktioner planlægges et undervisningsforløb i samarbejde med den afasiramte og eventuelt pårørende. Undervisningen tager sit afsæt i det kognitive og udvikler sig derfra individuelt videre med et overordnet mål om genetablering af sprogproduktion og/eller mod et mål om aktiv deltagelse i sociale sammenhænge. Hjerneforsker Kjeld Fredens advarer mod alene at tage udgangspunkt i billeddiagnostik, da hjerner er konstruerede efter det liv mennesket har levet (Konnerup \& Schmidt 2006). Dette betyder, at den pædagogiske diagnose skal veje tungt $\mathrm{i}$ planlægningen af genoptræningen, og at der vedvarende skal justeres og reformuleres i undervisningsmål.

Ifølge Goldberg har forskning vist, at mental aktivitet udvikler hjernen, og at der selv efter en hjerneskade kan udvikles nye nerveceller og baner. Han beskriver, hvordan et hjernetræningsprogram med kognitiv fitness kan være med til at opretholde et intellektuelt niveau og hæmme hjernemæssigt forfald. Han opererer med begrebet kognitiv empowerment i forhold til det at få genoprettet forbindelsen til sine kognitive evner, selv at kunne tage ansvar og besidde kompetencer i forbindelse med sygdom og efter hjerneskade. Et virtuelt kommunikations- og læringsmiljø kan tilbyde de læringsrammer, der netop giver mulighed for kognitiv fitness i et socialt fællesskab.

\section{Afasiramte og virtuelle læreprocesser}

Et fokusgruppeinterview med afasiramte og pårørende på Taleinstituttet, fortaget af Konnerup og Schmidt i forbindelse med masterprojekt i Ikt og Læring (Konnerup \& Schmidt 2006) viser, at rehabilitering i et virtuelt miljø betragtes som værdigt overfor venner og familie, og vidner om, at man stadig kan "følge med tiden." Det at beherske nyere kommunikationsformer, som chat, mail og blogs, giver større mulighed for at kommunikere "på lige fod" med omverdenen og være en aktiv deltager. Det har dog betydning, at den afasiramte tilbydes en strukturel ramme for anvendelsen af internettet. Basecube fungerer som indgangsdør til internettet. De afasiramte betragter det som deres arbejdsplads, som de hver dag skal "ind på". Deltagerne føler et fællesskab på Basecube, og de er trygge ved at kommunikere med hinanden.

\section{Udnyttelse af uformelle læreprocesser i den formelle læring}

Genoptræningen er et formaliseret læringstilbud, hvor det handler om at styrke kommunikative kompetencer. I et virtuelt tilbud til afasiramte er det 
vigtigt med en formel ramme, der kan fungere som indgang til Internettet, og som skaber tryghed og fællesskab. Opgaverne i Basecube er en del af den formelle læring. Målrettet søgning på internettet efter oplysninger til en opgave er ligeledes en formel læreproces, men når så nysgerrigheden vækkes og man finder et spændende link, der bringer én til et nyt sted - når søgningen bliver mindre målrettet, så skifter læreprocessen karakter fra det formelle til det uformelle. Det spændende og udfordrende ligger i at kunne inddrage og udnytte de uformelle læreprocesser i den formelle læring. I Basecube har man søgt at samle både den formelle træning, opgaverne, og den uformelle, læsning af nyheder via en rss ${ }^{6}$-funktion, direkte link til Skype og debatfora i én samlet flade. Hensigten er at skabe et virtuelt miljø, hvor deltagerne kan logge sig på så ofte som muligt, ikke nødvendigvis for at træne formelt, men for at checke post, læse nyheder, være i dialog, checke børsnoteringer mm. Ideen er, at disse handlinger, det vi kalder de uformelle læreprocesser, dels skal styrke handle- og kommunikationskompetencerne, dels give øget motivation og sammenhæng til den mere formelle træning. Drivkraften til at logge sig på er, at man skal se, om der er sket noget nyt, og om der er andre på. Specielt det at kunne læse nyheder har været en motivationsfaktor for mange, da det som afasiramt kan være vanskeligt at bladre og orientere sig i en papiravis eller følge med i en TV-avis med mange hurtige skift. Via Basecubes nyhedskanaler kan man linke til udvalgte nyheder og TV-avis-indslag på internettet, se indslagene gentagne gange, pausere eller kombinere med en skriftlig nyhed om samme emne. Via læsning af nyheder på internettet fører det ene link hurtigt det andet med sig, og på den måde konstruerer man sin egen sammensætning af information efter interesse og motivation (Konnerup \& Schmidt 2006).

Det er væsentligt, at talepædagogen hjælper med at facilitere disse uformelle processer ved at opfordre til forskellige former for dialog og meningsforhandling deltagerne imellem. Samtidig bliver det et vigtigt redskab for talepædagogen at deltage i nogle af de uformelle læreprocesser. Det giver en indsigt i de afasiramtes tanker og liv og bidrager til at kunne give konstruktiv feedback og støtte i den formelle træning.

\section{Nye roller}

Rollefordelingen mellem afasiramt og talepædagog i den virtuelle undervisning, understøttet af Basecube, adskiller sig på en række punkter fra den, vi kender fra den traditionelle undervisning i et fysisk samvær. Afstanden mellem afasiramt og talepædagog mindskes ved at lade den afasiramte tage initiativ og et større ansvar for læringen. Samtidig sker kommunikationen omkring fællesaktiviteter nu på Basecube, hvilket flytter kommunikationen fra at være et anliggende udelukkende mellem én afasiramt og én talepædagog til at være et fælles anliggende mellem alle deltagere, både afasiramte og talepædagoger.

\section{Talepæedagogen}

I den virtuelle læring har talepædagogen flere roller, hvoraf nogle er nye i forhold til den traditionelle undervisning. Talepædagogens arbejde kan

\footnotetext{
${ }^{6}$ RSS (eng: Really Simple Syndication) er en betegnelse, som bruges om en familie af filstandarder baseret på XML-data, der gør det muligt for webbrugerne at få kanaliseret f.eks. nyhedsoverskrifter fra websites hjem til computeren - uden at besøge websiderne. (http://da.wikipedia.org/wiki/RSS ).
} 
karakteriseres som stilladsering (Wood et al. 1976), hvor han/hun opstiller rammer for læring, motiverer og støtte den lærende. Samtidig er rammerne udvidet, så der nu ikke kun er tale om at skabe rammer for formel læring, men i lige så høj grad at skabe rammerne, så uformel læring faciliteres.

I den almindelige undervisning er talepædagogen "på", når der er undervisning. I den virtuelle læring suppleres den fastlagte online undervisning af muligheden for at kunne træne og kommunikere på alle tider af døgnet. Det medfører, at talepædagogen får en anden opmærksomhed på deltagerne, hvor det handler om at gribe tiltag, give feedback og bringe kommunikationen og læringen videre. Det gælder ikke kun i forhold til de stillede formelle opgaver, men også i forhold til asynkrone diskussionstråde eller spontane synkrone henvendelser via Messenger eller Skype. Ved sidstnævnte form for kommunikation ligger der en læring i både det at skrive, læse og tale, men også undervisning i netetikette og kommunikativ turtagning7.

Tilgangen til en opgave varierer fra deltager til deltager, og det gælder om at udnytte de muligheder, der ligger i det virtuelle for at tilpasse indholdet til den enkelte og hele tiden observere og udfordre således, at man finder noget, der fænger og interesserer den lærende.

Både i de formelle og de uformelle læreprocesser er det nødvendigt konstant at fokusere og justere på rammerne således, at den afasiramte når de mål, der har størst betydning for ham/hende. De fleste deltagere logger på Basecube dagligt, og når der ligger noget nyt, vækkes nysgerrigheden. En anden måde er hurtigt at give respons på indlæg og opgaver. Gennem positiv feedback er det muligt for den afasiramte at foretage en ny korrigeret handling. Det er gennem interesse, diskussion og refleksion over en opgave, læringen sker.

\section{Den afasiramte}

Den afasiramte bliver aktivt handlende og medskaber af rammerne for egen læring. Læreprocessen er i centrum, og han/hun skal selv have hel eller delvis kontrol over sin egen læring. I den traditionelle undervisning er den afasiramte også medansvarlig for læreprocessen, men da en stor del af den virtuelle læring foregår på eget initiativ, er en større del af ansvaret overdraget den enkelte. De afasiramte er endvidere med til at konstruere rammerne ikke kun for læringen, men også for omgivelserne. Brugerne af Basecube har været med under designforløbet, og der er et åbent debatforum, hvor design og programmering kan kommenteres og diskuteres.

Opgaverne i Basecube udformes, så man kan udvælge det, man har lyst og interesse i at se nærmere på. Derved kan den afasiramte træffe valg og selv tage ansvar for egen læring. Udfordringen for talepædagogen er således at lave opgaver, der motiverer til handling.

\footnotetext{
${ }^{7}$ Det at "spille ping-pong" i en samtale.
} 


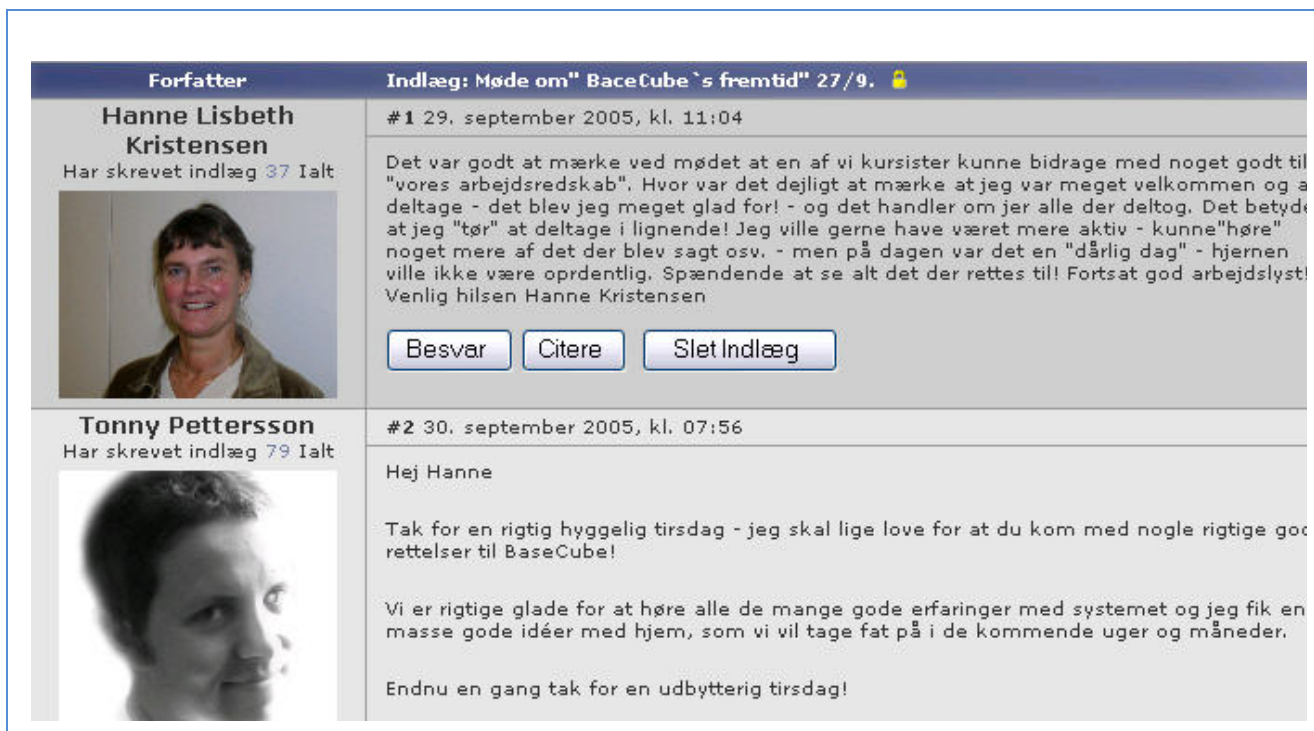

Figur 8. Dialog mellem designer og afasiramt om udviklingsmuligheder i Basecube

\section{De pårørende}

Den aktualitet, det er muligt at give opgaverne i Basecube, er med til at skabe interesse hos pårørende. De begejstres af, at de afasiramte er opdaterede med, hvad der sker i verden, og således kan være kommunikativt deltagende i hjemmet og i andre sociale sammenhænge. Det betyder endvidere noget for pårørende, at de afasiramte via internettet kan varetage nogle af de opgaver, de havde i familien, før de blev ramt, indkøb, bank o. lign. Det er med til, at balancen og rollefordelingen i familien genoprettes, således at pårørende ikke har ansvar for alt.

\section{Virtuelle praksisfællesskaber - sociokulturelt læringssyn}

Som nævnt er Basecube designet på baggrund af en socialkulturel tilgang til læring. Et sociokulturelt læringssyn bygger på en konstruktivistisk anskuelse, der anerkender kognitionens betydning, og samtidig ser den i et tæt samspil med social interaktion. Der findes overordnet to retninger inden for teorier om konstruktivistisk læring - en kognitiv med rødder tilbage til Piaget, og en socialkonstruktivistisk, der har rødder til Vygotsky. Designet er især stærkt inspireret af Lave og Wengers tanker om læring som deltagelse i sociale sammenhæng (Lave og Wenger 2003; Wenger 2004). Lave og Wenger (2003) beskriver læring som situeret i praksisfællesskaber, hvor læringen strækker sig ud over den pædagogiske struktureringskontekst og inddrager den sociale verden. Udover at betragte læring som et middel til udvikling af praksis kan læring også anskues som et middel til udvikling og forandring af identiteter (Wenger 2004:24).

Når man taler om læring i forhold til genoptræning af sprog vil kognitiv læringsforståelse have fokus på sprogproduktion, mens en socialkonstruktivistisk læringsforståelse har fokus på sprogets funktion og sociale interaktion. 


\section{Deltagelse i praksisfællesskaber}

Det har stor betydning for læring, identitet og selvværd at være en del af et fællesskab, både med ligestillede og med familie og venner. Et af kendetegnene for et praksisfællesskab er gensidigt engagement og deltagelse (Wenger 2004). Ønsker man at skabe fællesskab i et virtuelt læringsmiljø, er det nødvendigt at fokusere på et fælles mål, som bliver fællesskabets omdrejningspunkt. Hver deltager kommer med sit eget repertoire, sin egen historie, som skal formidles, og i denne formidling spiller det narrative en vigtig rolle, hvor profiler og blogs både styrker den enkeltes opfattelse af egen identitet og synliggør overfor de øvrige deltagere, hvem man er. Gennem fælles oplevelser, et fælles repertoire med andre deltagere, skabes en fælles kultur og identitet.

Det virtuelle fællesskab, som praktiseres i Basecube, skal ses i kombination med fysiske møder. De afasiramte, der er tilknyttet Basecube, mødes ca. hver anden måned. For vores målgruppe betyder det meget, at læringen er "blended", med regelmæssige aktiviteter i det fysiske rum. Det styrker fællesskabet og skaber tryghed. Deltagere, der har svært ved at gøre sig kommunikativt gældende i diskussionsfora på Basecube, inddrages i fællesskabet.

\section{Identitet}

Identitet skabes gennem kommunikation i sociale fællesskaber og er noget, der skal opretholdes og vedvarende genfortælles gennem sproget med fortællinger og billeder. Hukommelse er en kognitiv funktion, der knytter sig til mange forskellige områder i hjernen, og mange afasiramte vil få hukommelsesvanskeligheder af en eller anden karakter. Dette påvirker identitetsdannelsen. Den biografiske hukommelse er opbygget som en narrativ fortælling (Fredens i: Konnerup og Schmidt 2006). Det kan være svært for en afasiramt med begrænsede kommunikative kompetencer og hukommelsesvanskeligheder vedvarende at fortælle sin historie, men Basecube tilbyder en mulighed for selvpræsentation. Med blogs og profil kan man i ord og billeder præsentere og fastholde sig selv, sin familie og sin historie, og dermed styrke hukommelsen.

Identitet skabes gennem de praksisser, man engagerer sig i, uanset hvilken grad af deltagelse man har (Wenger 2004). Gennem dialog og meningsforhandling i et virtuelt miljø, både synkront og asynkront, hvor deltagerne gensidigt kan genkende sig selv i ligestillede, formes identiteten i praksisfællesskabet. Wenger bruger betegnelsen legitim perifer deltagelse om processen, gennem hvilken nyankomne bliver en del af et praksisfællesskab (Lave \& Wenger 2003:31). Det omfatter aktiviteter, identiteter, artefakter, samt fællesskaber af viden og praksis. Deltagelse ses ikke som noget, man kan "tænde og slukke for", men som noget, der bliver inkorporeret i hele vores liv, som en konstituerende del af vores identitet (Wenger 2004:184). Fokus er på de gensidige relationer mellem veteraner og nyankomne i praksisfællesskaber, hvor læring og udvikling forstås som meningsforhandling mellem aktørerne. Deltagelsen kan dog have forskellig karakter, og i forhold til Basecube ses da også forskellige grader af synlig aktivitet. Flere nyankomne har en mere perifer deltagelsesrolle, hvor de på grund af manglende skriftlig og verbalsproglig kompetence ikke selv bidrager med indlæg, men er synlige via online-listen og deres oprettede profil. På den måde bliver de, gennem 
identifikation med de andres beskrevne problemstillinger, legitime deltagere i fællesskabet og opbygger herved en identitet.

På trods af mulighederne for brug af billede og lyd i sin selvpræsentation, er den skriftlige kompetence det stærkeste kommunikationsmiddel i Basecube, og de, der således ikke har en skriftlig kompetence, bliver perifere deltagere, hvor den primære kommunikation foregår tovejs til talepædagogen. Det er her talepædagogens opgave at støtte og motivere, så de perifere deltagere bliver mere og mere deltagende.

\section{Meningsforhandling}

Det virtuelle læringsmiljø kan understøtte meningsforhandling mellem de involverede deltagere og således give mulighed for interaktion og refleksion. Formålet med at skabe rum for meningsforhandling er at facilitere læreprocesser, både formelle og uformelle. I nævnte fokusgruppe-interview gav pårørende udtryk for, at en del af den meningsforhandling, der føres i Basecube omkring opgaverne, fører de afasiramte med sig til aftensbordet, og de bliver således i stand til at diskutere aktuelle begivenheder med familien. Når en opgave har været bearbejdet sprogligt, både skriftligt og mundtligt, sættes begreberne på plads, så det er muligt at bruge dem i en senere meningsforhandling. De afasiramte får herved mulighed for at gøre sig kommunikativt gældende. Det er væsentligt, at kunne fastholde meningskonstruktion og kommunikationshandlinger gennem en fælles videndatabase, så det er muligt at drage det frem igen. I Basecube gemmes alle løste opgaver i et privat opgavearkiv, fælles diskussioner og artikler arkiveres i et offentligt arkiv, tilgængeligt for de deltagere, der har kunnet læse artiklerne. Det kan bruges i forhold til refleksion over egen læring, og til at se at der er sket en udvikling.

\section{Interaktion}

Deltagelse er et vigtig parameter i læringen, og der skal skabes mulighed for, at deltagerne kan interagere med mediet, med talepædagog og med hinanden $\mathrm{i}$ form af både synkron og asynkron dialog. Interaktion med mediet sker via links, der kan føre vidt omkring i det virtuelle miljø. Det er nysgerrigheden, der styrer denne interaktion. Målet er læring og identitetsdannelse, læring om specifikke emner, begreber og ord. Interaktion mellem afasiramt og talepædagog foregår dels i forbindelse med virtuel undervisning, hvor formelle opgaver i Basecube diskuteres, men der sker også uformel læring, hvor der meningsforhandles om små ting fra hverdagen. Ved at skrive eller tale om en forestående handling, f.eks. et møde med en sagsbehandler, rustes den afasiramte til mødet. Meningsforhandling mellem de afasiramte kan betragtes som en uformel læreproces. Det er en proces som talepædagogen forsøger at facilitere ved løbende at lave små diskussionsoplæg, der kan diskuteres asynkront i Basecubes debatfora eller synkront som chat eller på Skype. Da deltagerne har forskellige styrker/svagheder i forbindelse med kommunikation, er det vigtigt at opfordre til at bruge forskellige kommunikations-former.

\section{Handle- og kommunikationskompetencer}

Genoptræning i Basecube skaber en fortrolighed med internettets mange muligheder, så det falder de afasiramte naturligt at søge oplysninger og 
foretage indkøb på internettet. Derved øges deres handlekompetence, og det er samtidig med til at skabe selvværd og identitet.

Ved at anvende flere perceptionsformer i sprogtræningen styrkes de kommunikative kompetencer. I et virtuelt miljø er det muligt at kombinere formerne, således at ord og begreber tilegnes både auditivt og visuelt og diskuteres skriftlig og mundtligt, for derved at sidde bedre fast. Skriveprocessen fungerer som et refleksionsredskab, mens den mundtlige dialog er vigtig for at omforme den indre dialog til en ydre. I bevægelsen fra indre til ydre sprog sker en erkendelse og manifestering af tankeplanet.

Kommunikative regler, som eksempelvis turtagning, kan være læderet efter en hjerneskade. Disse regler er vigtige i alle former for kommunikation, men i internetkommunikation som chat eller stemmesamtale er det nødvendigt at vente og forholde sig til det, samtalepartneren skriver eller siger for at samtalen skal kunne fungere. Brud på regler i turtagning ses tydeligt. I stemmesamtaler påvirker det lydkvaliteten, hvis der tales i munden på hinanden og i chat forsvinder det skrevne, inden samtalepartneren får svaret, hvis der skrives for lange enetaler. Omvendt er formen i chat uformel og tillader uafsluttede og ukorrekte sætninger, der kan krydres med fortællende symbolsprog.

Læring i Basecube er med til at styrke en øget handlekompetence. Et eksempel på, at en deltager overfører fortroligheden fra Basecube til andre virtuelle handlinger, er udnyttelsen af virtuelle lægebesøg (figur 9).

Livskvaliteten øges, når man har mulighed for at være en aktiv deltager i familie og samfund og selv kan tage ansvar for handlinger som eksempelvis lægebesøg, gaver og indkøb. Øget livskvalitet skaber glæde og vil virke fremmende på hukommelse og læring.

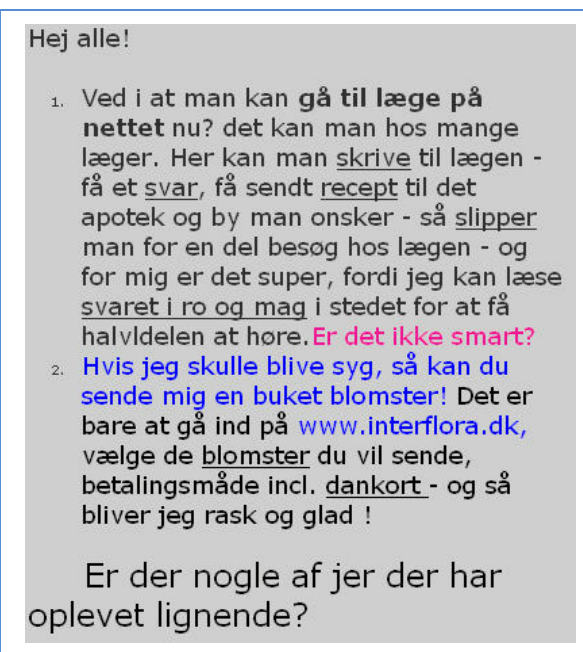

Figur 9. En afasiramt, der gør opmærksom på virtuelle handlemuligheder 


\section{Perspektivering - teser om avatar-medieret interaktion}

På baggrund af erfaringerne med genoptræning i Basecube og udnyttelse af web 2.0 teknologier har forfatteren i efteråret 2009 påbegyndt et $\mathrm{PhD}$ projekt, der undersøger hvorvidt 3D immersive virtuelle verdener (IVV) tilbyder nye genoptræningsmuligheder for målgruppen. Forskningsprojektet baserer sig på en hypotese om, at inddragelse af krop og nonverbale aktiviteter i form af en avatar ${ }^{8}$ medieret kommunikation vil påvirke hjernens reetableringsproces positivt og fremme kognitive og kommunikative funktioner. 3D IVV giver mulighed for at anvende flere sansestimuli på én gang og således udnytte, at der er flere ledetråde til stimulering og udvikling af nervebaner i hjernen. Endvidere kan oplevelser og handling på forestillingsniveau ifølge teorier om spejlneuroner stimulere nerveceller og udvikle dem på ny (Rizzolatti 2008). Ideen er således, at afasiramte kan agere og kommunikere i et virtuelt læringsmiljø, ikke blot ved at høre, se, tale og skrive, men også ved at forestille sig handlinger gennem en avatar-repræsentation af sig selv. Hypotesen er således, at et menneskes hjerneaktivitet, ved at interagere avatar-medieret $\mathrm{i}$ en virtuel verden, vil spejle det, som avataren foretager sig. Spejlneuronerne gives herved mulighed for at informere og aktivere andre cellesystemer, der kan igangsætte specifikke processer i mennesket, f.eks. aktivere nervebaner, der medvirker til kommunikation.

Et andet interessant aspekt af den avatar-medierede kommunikation er den kropslige 'immersion', da målgruppen enten har fysiske eller kognitive begrænsninger og handicaps. Gennem avatarer øges mulighederne for interaktion og kommunikation. Deltagerne tilbydes en mulighed for at mødes og interagere i særlige designede 3D-rammer, der tilvejebringer en følelse af tilstedeværelse, som mange andre medier mangler. Ud over den tekstlige og billedmæssige repræsentation vha. smileys og emoticons gør avatarer det muligt at anvende forskellige registre af bevægelser og følelsesytringer. De kan vinke, danse, slås, kysse mm., og derved vise et bredere spektrum af nonverbal kommunikation. Interaktionen imellem avatarer (og menneskene bag dem) er en ny dimension, som er vigtig at medtænke i rehabilitering af afasiramte. Påvirker repræsentation af kroppen i virtuelle miljøer hjernen positivt? Hvad bibringer fornemmelsen af fysisk og social tilstedeværelse?

Disse mange muligheder har ført hen til følgende forskningsspørgsmål for forfatterens igangværende $\mathrm{PhD}$ projekt:

Hvorledes kan deltagelse og interaktion i 3D immersive virtuelle verdner udvikle, socialisere og genoptræne handle- og kommunikationskompetencer samt kognition hos mennesker med erhvervede hjerneskader? Herunder spørgsmålet om, hvordan 3D immersive virtuelle verdener tilbyder målgruppen gendannelse af personlighed, skabelse af identitet og tilegnelse af viden $i$ et aktivt samspil med både medie, andre deltagere, fagpersoner og pårørende?

Konkret er planen at designe et 3D IVW, hvor en gruppe afasiramte og talepædagoger skal træne, agere, kommunikere immersivt og avatar-medieret via web 2.0-teknologier. Gennem pilotforsøg og forskning af aktiviteterne søges svar på nævnte spørgsmål.

\footnotetext{
${ }^{8}$ En grafisk repræsentation af en person eller figur på internettet.
} 


\section{Konklusion}

Den talepædagogiske praksis befinder sig i en brydningstid, dels som resultat af en strukturreform, der ændrer rammefaktorerne for genoptræning, dels på baggrund af et ønske om på landsplan at have standardiseringer af genoptræning (Villadsen et al 2007).

Der efterlyses evidensbaserede metoder til at undersøge effekten af genoptræningstilbuddene. Med et funktionalistisk syn på sproget og et konstruktivistisk syn på hjerneprocesser og læring kan det være svært at måle kvantitativ effekt af et undervisningsforløb, når effekten ligger i personen og relationen til omverdenen. Det kræver et stort repertoire af evalueringsformer, og der må udvikles nye metoder, hvor det handler om at kortlægge personen. Med inddragelse af ikt er der en række potentialer for at udvikle evidensbaserede metoder, der kan belyse den relationelle rehabilitering. Gennem virtuel portefølje, logbøger og weblogs er der direkte adgang til og dokumentation for den afasiramtes genoptræningsforløb. Desuden er det muligt via programmer som eks. Camtasia ${ }^{9}$ at logge interaktive forløb. Metoderne rummer både kvantitative og produktorienterede resultater, samt mere kvalitative, procesorienterede eller narrative præsentationer. De beskrevne metoder vil dog altid kræve en subjektiv tolkning, og resultaterne er ikke nemme at rubricere.

Nye teknologier i undervisningen skærper bevidstheden om, hvilke læreprocesser man ønsker at sætte i spil. I relation til mennesker med en erhvervet sprogforstyrrelse giver forskellige aspekter af e-læring og iktværktøjer mulighed for ikke blot at genoptræne eller kompensere for det tabte sprog - men også lade det gamle tabte sprog erstatte af et nyt sprog medieret af ikt. Nye teknologier giver mulighed for at ændre nogle sproglige strategier, nå intakte sider af sproget og udvikle en anderledes form for kommunikation. Det virtuelle åbner således for undervisningsformer, der ved at få alle kognitive funktioner i spil faciliterer nye læreprocesser. Der er her gode muligheder for at arbejde med autenticitet og aktualitet, og dermed inddrage det personlige, det narrative og det biografiske som midler til at fremme selvrefleksion, metakognition og genfortælling af sin identitet.

Gennem aktiv deltagelse og meningsforhandling i virtuelle tilbud er det muligt at genoptræne kommunikative evner. Ved at anvende flere perceptionsformer styrkes afasiramtes handlemuligheder. Med et bredt funktionalistisk syn på sprog, hvor sproget er involveret i alle kognitive processer, afspejler sproget hele menneskets eksistens. Afasi bliver da langt mere end tab af sprog og påvirker hele menneskets eksistens. Den sproglige genoptræning omfatter mere end sprog, det er hele det sociale og kognitive aspekt, det er handle- og kommunikationskompetencer bredt, det er genskabelse af identitet. Virtuelle læringsmiljøer giver mulighed for at tilføre rehabiliteringen et samlet tilbud, hvor alle ovenfor nævnte aspekter involveres.

Når læringsmiljøet designes i 3D, og læringen foregår i IVW, bliver det muligt at kombinere mange af de elementer, som har gjort web 2.0 interessant: muligheden for at forbinde sig med venner, skabe sociale netværk, og danne fællesskaber, samt oplevelsen af tilstedeværelse i disse fællesskaber med en

\footnotetext{
${ }^{9}$ http://www.techsmith.com/camtasia.asp
} 
kropslig repræsentation af sig selv - en avatar. Hypotesen er, at denne øgede mulighed for følelse af tilstedeværelse vil påvirke kommunikation, læring og reetablering af hjernen positivt.

\section{Referencer}

Bjarkam, C. R. (2004). Neuroanatomi, 1 udg., Munksgaard Danmark, København.

Fredens, K. (2004). Mennesket i hjernen - en grundbog i neuropædagogik. Århus: Systime Academic.

Gade, A. (1997). Hjerneprocesser København: Frydenlund.

Goldberg, E. (2005). Visdommens paradoks. København: Psykologisk Forlag

Lave, J. \& Wenger, E. (2003). Situeret læring og andre tekster. København: Hans Reitzels Forlag.

Luria, A.R. (1983). Hjernen. København: Nyt Nordisk Forlag Arnold Busck.

Konnerup, U. \& Schmidt, D. (2006). Det virtuelle miljø - en mulighed for nye læreprocesser i rehabiliteringen af afasiramte. Masterspeciale ved master i IKT og Læring, Institut for Kommunikation Aalborg Universitet.

Nicolaisen, K. \& Vejleskov, H. (1996). Dysfatiske småbørn. Danmarks Lærerhøjskole.

Petersen, K., Konnerup, U. \& Dirckinck-Holmfeld, L. (2004). Ansigt til ansigt - fjernundervisning af afasiramte. Evalueringsrapport, del 1, 2 og 3. Aalborg: E-Learning Lab \& RECIT, Aalborg University.

Petheram, B. (2004). Computers and aphasia: A means of delivery and a delivery of means. Aphasiology 18 (3), 187-191.

Pettersson, T. (2004). Nye grænseflader. Projektopgave på Humanistisk Informatik - multimedielinien. Aalborg Universitet.

Rizzolatti, G. (2008). Mirrors in the Brain. Oxford: University Press

Svenstrup, L. (2004). Sprog og personlighed - Om sprogets rolle $i$ opfattelsen af egen og andres personlighed. I: M. Rathje og L. Svenstrup: Sprogpsykologi. København: Museum Tuscelanum

Villadsen, M. H., Myhlendorph, L., Porskjær, T., Lund, V., Rossing, A \& Randrup Jensen, L. (2007). Vejledning i udredning af afasi http://www.dths.dk/taleomraadet.htm . Sidst tilgået 20. juni 2010.

Villadsen, M.H., Myhlendorph, L., Porskjær, T., Lund, V., Rossing, A., og Randrup Jensen,

Vestberg, P. (2002). Hjerneskade og personlighed. http://www.birgittegammeltoft.dk/artiklernye/artikler/hjerneskade og_personlighed.htm. Sidst tilgået 28. februar 2010 . 
Vygotsky, L. S. (1971). Tænkning og sprog. Bd. I \& II. København: Hans Reitzel.

Wenger, E. (2004). Praksisfællesskaber. København: Hans Reitzel.

Wood, D., Bruner, J. \& Ross, G. (1976). The role of tutoring in problem solving. Journal of Child Psychology and Psychiatry. 17(2): 89-100. 